\title{
EFFECTS OF DURATION AND LEVEL OF FEED RESTRICTION ON PERFORMANCE AND MEAT QUALITY OF BROILER CHICKENS
}

\author{
EFECTOS DE LA DURACIÓN Y NIVEL DE RESTRICCIÓN ALIMENTICIA SOBRE LA \\ PRODUCCIÓN Y CALIDAD DE LA CARNE DE POLLOS DE CARNE
}

\author{
Omosebi, D.J. ${ }^{1}$; Adeyemi, O.A. ${ }^{1}$; Sogunle,M.O. ${ }^{1}$; Idowu, O.M.O. ${ }^{2}$ and Njoku, C.P. ${ }^{1}$
}

${ }^{1}$ Department of Animal Production and Health. University of Agriculture. Abeokuta. Ogun State. Nigeria. ${ }^{2}$ Department of Animal Nutrition. University of Agriculture. Abeokuta. Ogun State. Nigeria.

\section{AdDitionAL KEYWORDS}

Abdominal fat. Marshall broilers. Cost benefit. Feed:gain ratio.

\section{SUMMARY}

Two hundred and sixteen unsexed 14 daysold Marshall broiler chicks were used in a $3 \times 3$ factorial experimental design to test the effect of restricting feed intake of birds by $0 \%, 20 \%$ and $40 \%$ levels for 2, 4 and 6 weeks after two weeks of the starter phase. The unrestricted (control) treatments were fed ad libitum throughout the experiment. The experiment lasted for 42 days. Data were collected and calculated on weight gain, feed:gain, feed intake, mortality, proximate composition of meat and cost-benefit analysis. Data obtained were subjected to a 2-way analysis of variance. Results showed significantly higher $(p<0.05)$ final weights in the unrestricted birds (control) compared to the restricted birds. Interaction between duration of restriction and level of restriction indicated that weight gain and feed intake significantly $(p<0.05)$ reduced as duration and level of feed restriction increased. Feed:gain was significantly $(p<0.05)$ different across the treatments with birds restricted at 40 $\%$ for 6 weeks having the best feed:gain (1.91). The mortality recorded was not significant $(p>0.05)$ across duration and level of restriction. Abdominal fat decreased with increasing duration and level of restriction with birds on $40 \%$ level and 6 weeks duration of restriction having the lowest fat content $(0.20 \%)$. Crude protein content of the breast muscle significantly increased while crude fat content of the breast muscle significantly decreased with duration and level of restriction. Crude fat content was lowest at $40 \%$ level and 6

\section{Palabras ClaVe ADICIONALES}

Grasa abdominal. Broilers Marshall. Coste/beneficio. Conversión alimenticia.

weeks duration of feed restriction. As level and duration of feed restriction increased, feed cost/ $\mathrm{kg}$ reduced. Birds restricted at $40 \%$ level for 2, 4 and 6 weeks durations respectively had better cost benefit than birds restricted at 0 and $20 \%$ levels for 2, 4 and 6 weeks durations. It can be concluded that the best feed:gain, lower abdominal fat, higher protein and better cost benefit was achieved in birds restricted at $40 \%$ for 6 weeks.

\section{RESUMEN}

Durante 42 días, 216 pollos broiler Marshall, de 14 días, fueron empleados en un diseño experimental factorial $3 \times 3$ para estudiar el efecto de la restricción de la ingestión de alimento en 0, 20 y $40 \%$, durante 2, 4 y 6 semanas en la fase de iniciación. El tratamiento control (no restringido) recibió alimentación ad libitum durante todo el experimento. Se obtuvieron datos sobre ganancia de peso, alimento/peso, ingestión, mortalidad, composición de la carne y relación coste beneficio. Los datos obtenidos se sometieron a un análisis de varianza de dos vías. Los resultados mostraron mayor peso final $(p<0,05)$, en las aves sin restricción, la interacción duración*nivel de restricción indicó que tanto la ganancia de peso como la ingestión, se redujeron cuando aumentaron la duración y nivel de restricción. La relación alimento/ganancia fue diferente $(p<0,05)$ entre tratamientos siendo la mejor $(1,91)$ en las aves con restricción de $40 \%$ durante 6 semanas. No hubo 
diferencias $(p>0,05)$ en la mortalidad registrada. La grasa abdominal disminuyó al aumentar la duración y nivel de restricción, alcanzando el menor contenido $(0,20 \%)$ en los niveles más intensos de restricción. El contenido proteico de la pechuga aumentó y su contenido graso se redujo al aumentar el tiempo y nivel de restricción. El contenido graso fue igualmente menor en los niveles mas intensos de restricción. Cuando la restricción se hacía mayor, el coste por kg producido se reducía. Las aves con restricción del 40 $\%$ tuvieron en todo el tiempo mejor relación coste beneficio que las de control y las de restricción del $20 \%$. Se puede concluir que con la restricción del $40 \%$ durante seis semanas se consigue mejor transformacion de alimento, menor grasa abdominal, mayor cantidad de proteína, y mejor relacion coste beneficio.

\section{INTRODUCTION}

Increased cost of feeding and early fat deposit are few of the problems of poultry farmers (Smith, 1990). It is generally assumed that when birds eat more, they have higher body weight at market age (Urdaneta-Rincon and Leeson, 2002). Feeding strategies in growing broiler chickens should be aimed at optimizing lean carcass tissue, feed conversion ratio (FCR) and body weight gain (Gous and Cherry, 2004; Teimouri et al., 2005). Nutrient restriction is usually employed to tackle problems that accompany early-life fast growth rate in broilers, such as increased body fat deposition, high incidence of metabolic disorders, increased mortality, and high incidences of skeletal diseases (Crouch, 2000; Saleh et al., 2005; Rezaei et al., 2006). Early feed restriction in broilers is practiced to induce catch-up growth and efficiency of feed utilization (Hocking et al., 2002; Teimouri et al., 2005). Response to feed restriction, however, depends on the duration of feed restriction. Prolonged feed restriction diminishes the potential of compensatory growth (Gous and Cherry, 2004; Leeson and Summers, 2005). Feed restriction programs have shown the potential to reduce the incidence of such problems can be used to modify birds growth patterns by decreasing their maintenance requirements, which should improve feed efficiency (Urdaneta-Rincon and Leeson, 2002).

Feed restriction has been adopted in broiler production to avoidrapid growth rate, which is associated with ascites, lameness,mortality, and poor reproductive results (Mench, 2002; Tolkamp et al., 2005). In addition, feed restrictionin the early stage is beneficial for improving the feed efficiency and decreasing the breeding cost (Zubair and Leeson, 1994). Although early feed restriction reduces growth performance, compensatory growth in the refeeding period will be attainedto accelerate organism growth to reach the weight of animals (Hornick et al., 2000; Pinheiro et al., 2004).

Excessive fat deposition is one of the main problems faced by the broiler industry these days, since it does not only reduce carcass yield and feed efficiency but also causes rejection of the meat by consumers (Kessler et al., 2000) and causes difficulties in processing (Chambers, 1990). Recent reports on feed restriction during the growing period in broiler chickens indicate that restricting feed intake lowers body weight and carcass fat and improves feed efficiency with compensatory growth during refeeding (Al-Taleb, 2003).

Response to feed restriction, however, depends on the duration of feed restriction. Prolonged feed restriction diminishes the potential of compensatory growth (Leeson and Summers, 2005). This study is aimed at identifying the duration and level of restriction that will bring about lean carcass tissue, feed efficiency and cost benefits in broiler production.

\section{MATERIALS AND METHODS}

Experimental site. The study was carried out at the Poultry Unit of the Teaching and Research Farm Directorate (TREFAD), Federal University of Agriculture (FUNAAB), Abeokuta, Ogun State. It receives a mean 
precipitation of $1037 \mathrm{~mm}$ per annum.

Experimental birds and management. A total of two hundred and sixteen (216) day old Marshall broiler chicks with average weight of 45-55g each, purchased from a reputable hatchery were used for the study. On arrival, they were given water containing glucose as anti-stress before feeding. The chicks were brooded for two weeks using charcoal pot as a heat source. At the beginning of the experiment, the birds were randomly distributed into nine treatments with 3 replicates of 8 birds per replicate. Daily routine management practices were carried out such as supply of clean water, feed, observing for sick birds, checking for mortalities and appropriate record keeping. Administration of vaccines, antibiotics and multivitamin supplement was given when necessary. The experiment lasted for 42 days. The study protocol was approved and conducted in accordance with the Animal Ethics Committee guidelines of Federal University of Agriculture, Abeokuta, Nigeria (FUNAAB, 2013).

Experimental diet. The composition of the diet is shown in table $\mathbf{I}$. The ingredient composition ( \%) of the diet was on as-fed basis. The diet was based on feed composition used for growing rabbits on the Federal University of Agriculture Abeokuta, Teaching and Research Farm, which was developed in line with the recommendations of Aduku (2004) and Merck (2011). The major ingredients (i.e. maize, groundnut cake and soy bean meal) were milled through a screen mesh size of $2.5 \mathrm{~mm}$ in a hammer mill. Other ingredients were already in milled forms at the point of purchase. The various ingredients were individually weighed out in their milled form into a rotary feed mixer and mixed to get the experimental diet. The experimental feed was mixed in the research feed mill. The feed was fed in mash form. Three levels of quantitative feed restriction were used (0-ad libitum, 20 and $40 \%$ ) and three feeding restriction durations of 2, 4 and 6 weeks respectively. The birds were distributed randomly into nine treatments. Weekly feed supply of each chick was predicated on the findings of Aduku (2004). The birds were subjected to 2 weeks of restriction at 0,20 and $40 \%$ levels of feed requirement, respectively, 4 weeks of restriction at 0,20 and $40 \%$ levels, respectively and 6 weeks of restriction at 0 , 20 and $40 \%$ levels, respectively.

Experimental design. The experimental

Table I. Composition of the experimental feed. (Composicion del pienso experimental).

\begin{tabular}{lc}
\hline Feed ingredients & Composition (\%) \\
Maize & 45.00 \\
Soy bean meal (44\% CP) & 15.00 \\
Fish meal (72\% CP) & 1.00 \\
Groundnut cake & 12.50 \\
Wheat offal & 21.50 \\
Oyster shell & 1.50 \\
Bone meal & 2.50 \\
Lysine & 0.25 \\
Methionine & 0.25 \\
Salt & 0.25 \\
Vit./ Min. Premix* & 0.25 \\
Total & 100.00 \\
Analysis results & \\
Dry matter (\%) & 87.50 \\
Crude protein (\%) & 21.74 \\
Metabolisable energy (Kcal/kg) & 2850.85 \\
Crude fibre & 4.90 \\
Ether extract (\%) & 4.01 \\
Ash (\%) & 3.93 \\
NFE (\%) & 53.46 \\
Lysine (\%) & 5.91 \\
Methionine (\%) & 5.31 \\
Calcium (\%) & 1.49 \\
Phosphorus (\%) & 0.57 \\
Ca:P & 2.62 \\
Protein:Energy & 0.008 \\
\hline
\end{tabular}

${ }^{*}$ Composition per kg diet: Vit A: $40000 \mathrm{IU}$; Vit D: $800001 U$; Vit E: 40000 ng; Vitk $: 800$ mg; Vit $B_{1}: 1000$ $\mathrm{mg}$; Vit $\mathrm{B}_{2}: 6000 \mathrm{mg}$; Vit $\mathrm{B}_{6}: 500 \mathrm{mg}$; VitB12: $25 \mathrm{mg}$; Niacin: $6000 \mathrm{mg}$; Panthothenic acid: $2000 \mathrm{mg}$; Folic acid: 200 mg; Biotin: 8 mg; Mn: 300000 mg; Fe: 8000 mg; Zn: 20000 mg; Co: $80 \mathrm{mg}$; l: 400 mg; Se: 40 mg; Choline: $800000 \mathrm{mg}$. 
design used was $3 \times 3$ factorial design. There were two factors of feed restriction. Duration of restriction was at three periods (2, 4 and 6 weeks) while level of restriction was at three levels (0, 20 and $40 \%$ of total feed intake).

Data collection. The birds were weighed per replicate at the start of the experiment and subsequently on weekly basis. Weight gain was taken by calculating the difference between the final body weight and previous body weight. Feed intake was recorded weekly for each treatment per replicate while left-over feed was subtracted from the total feed given to the birds in order to determine feed intake. Feed: gain ratio was calculated as feed intake per g body weight gain.

The total number of dead broilers during the experimental trial were recorded and expressed as percentage (\%) of total number of birds alive at the start of the experiment.

Abdominal fat measurement and chemical analysis. At 56 days, two birds whose weight were close to the mean replicate weight were selected from each replicate, fasted overnight, slaughtered, manually defeathered and eviscerated and cut into retail parts. The abdominal fat pad was excised, weighed and expressed as a percentage of liveweight. Proximate analysis of the compounded ration and breast muscle were analyzed according to the method of (AOAC, 1995).

Cost benefit determination. The prevailing market prices of the feed ingredients at the time of the experiment were used to estimate the unit cost of the experimental diet. Feed cost per kilogramme and cost per kilogramme of weight gain were calculated. The percentage feed cost saving of broilers on restriction compared to the ad libitum fed broilers was also determined.

Statistical analysis. All data collected were subjected to a two-way analysis of variance in $3 \times 3$ factorial experimental design using a statistical package (SPSS, 1999). Significant $(\mathrm{p}<0.05)$ differences among variables were separated using Duncan's Multiple Range Test (Steel et al., 1997).

\section{RESULTSANDDISCUSSION}

The results of the experiment (table II) indicated that the control group had significantly higher performance than the restricted group. The results also indicated that the growth of broiler chicken is related to the feed intake supporting the evidence

Table II. Main effect of duration and level offeed restriction on Marshall broiler performance. (Efectos de la duracion e intensidad de la restricción alimenticia sobre el rendimiento de pollos broiler Marshall).

\begin{tabular}{|c|c|c|c|c|c|c|c|c|}
\hline \multirow[b]{2}{*}{ Parameters } & Duration & \multicolumn{3}{|c|}{ of feed restriction (weeks) } & \multicolumn{4}{|c|}{ Level of feed restriction (\%) } \\
\hline & 2 & 4 & 6 & SEM & 0 & 20 & 40 & SEM \\
\hline Initial weight(g) & 174.15 & 174.28 & 170.13 & 8.27 & 175.93 & 171.37 & 171.25 & 8.25 \\
\hline Final weight $(\mathrm{g})$ & $1945.56^{a}$ & $1822.22^{\mathrm{ab}}$ & $1713.33^{b}$ & 45.29 & $2097.78^{a}$ & $1683.33^{c}$ & $1700.00^{b}$ & 45.29 \\
\hline Total feed intake (g) & $3939.33^{a}$ & $3791.06^{a}$ & $3403.09^{b}$ & 98.68 & $4173.63^{a}$ & $3712.15^{b}$ & $3247.71^{c}$ & 98.68 \\
\hline Daily feed intake $(\mathrm{g} / \mathrm{b})$ & $93.79^{\mathrm{a}}$ & $90.26^{a}$ & $81.02^{\mathrm{b}}$ & 2.34 & $99.37^{a}$ & $88.34^{\mathrm{b}}$ & $77.32^{\mathrm{c}}$ & 2.34 \\
\hline Total weight gain (g/b) & $1771.41^{\mathrm{a}}$ & $1641.94^{b}$ & $1543.20^{b}$ & 26.78 & $1921.78^{a}$ & $1511.96^{b}$ & $1528.75^{b}$ & 26.78 \\
\hline Daily weight gain (g/b/d) & $42.18^{\mathrm{a}}$ & $39.24^{\mathrm{b}}$ & $36.74^{\mathrm{b}}$ & 0.63 & $45.76^{a}$ & $36.00^{\mathrm{b}}$ & $36.40^{\mathrm{b}}$ & 0.63 \\
\hline Feed: gain & $2.22^{\mathrm{ab}}$ & $2.30^{\mathrm{a}}$ & $2.21^{\mathrm{b}}$ & 1.04 & $2.17^{\mathrm{b}}$ & $2.45^{\mathrm{a}}$ & $2.12^{\mathrm{b}}$ & 1.04 \\
\hline Mortality(\%) & 2.77 & 4.16 & 4.16 & 1.99 & 4.16 & 2.77 & 4.16 & 1.99 \\
\hline
\end{tabular}

a,b,c,d Means in the same row not sharing common superscript are significantly different $(p<0.05)$. SEM: Standard error mean. 
that the body weight gain of broiler chickens could be inhibited by feed restriction (Washburn and Bondari, 1978). Lippens et al. (2000) and Urdaneta-Rincon and Leeson (2002) have argued that improvement in feed efficiency noted with the use of feed restriction programmes is due to reduced overall maintenance requirements because birds subjected to a period of feed restriction tend to have smaller body weights before they reach market weight thus they require less for this purpose. Urdaneta-Rincon and Leeson (2002) postulated that compensatory growth and associated reduction in maintenance feed requirements provide a promising method of reducing feed cost of broiler chickens. In this study, feed restriction reduced the growth of the birds according to the intensity of the duration and level (table III). However, it was apparent that the feed allocation allowed for some growth and maintenance. Body weight and feed intake at the end of the experiment were progressively reduced by increasing duration and level of feed restriction. In this study, reduction of final body weights for birds restricted for 6 weeks at $40 \%$ might have been at least due to birds not being

Table III. Interactive effect between duration and level offeed restriction on Marshall broiler performance. (Efecto interactivo entre la duración y nivel de restricción alimenticia sobre el rendimiento de pollos broiler Marshall).

\begin{tabular}{|c|c|c|c|c|c|}
\hline & $\begin{array}{l}\text { Duration } \\
\text { (weeks) }\end{array}$ & 0 & $\begin{array}{c}\text { Level } \\
20\end{array}$ & 40 & SEM \\
\hline \multirow[t]{3}{*}{ Initial weight (g/b) } & 2 & 178.30 & 173.32 & 170.83 & 9.46 \\
\hline & 4 & 177.83 & 172.5 & 172.5 & 8.26 \\
\hline & 6 & 171.67 & 168.3 & 170.42 & 8.37 \\
\hline \multirow[t]{3}{*}{ Final weight (g/b) } & 2 & $2133.30^{\mathrm{a}}$ & $1886.70^{\mathrm{ab}}$ & $1816.70^{\mathrm{ab}}$ & 45.29 \\
\hline & 4 & $2083.30^{a}$ & $1733.30^{\mathrm{b}}$ & $1650.00^{\mathrm{bc}}$ & 63.74 \\
\hline & 6 & $2076.70^{a}$ & $1541.47^{\mathrm{bc}}$ & $1511.00^{c}$ & 79.31 \\
\hline \multirow[t]{3}{*}{ Total weight gain $(\mathrm{g} / \mathrm{b})$} & 2 & $1955.00^{a}$ & $1713.38^{\mathrm{ab}}$ & $1964.87^{b}$ & 98.68 \\
\hline & 4 & $1905.47^{a}$ & $15608^{c}$ & $1477.5^{d}$ & 44.32 \\
\hline & 6 & $1905.3^{a}$ & $1373.17^{d}$ & $1341.58^{d}$ & 48.32 \\
\hline \multirow[t]{3}{*}{ Daily weight gain $(\mathrm{g} / \mathrm{b} / \mathrm{d})$} & 2 & $46.55^{\mathrm{a}}$ & $40.79^{a b}$ & $39.19^{b}$ & 2.34 \\
\hline & 4 & $45.37^{a}$ & $37.16^{c}$ & $35.18^{d}$ & 1.82 \\
\hline & 6 & $45.36^{a}$ & $32.69^{d}$ & $31.93^{\mathrm{d}}$ & 1.15 \\
\hline \multirow[t]{3}{*}{ Total feed intake $(\mathrm{g} / \mathrm{b})$} & 2 & $4043.04^{b}$ & $3940.26^{c}$ & $3834.70^{d}$ & 26.78 \\
\hline & 4 & $4248.51^{a}$ & $3781.91^{\mathrm{e}}$ & $3342.70^{g}$ & 18.42 \\
\hline & 6 & $4229.27^{a}$ & $3414.28^{f}$ & $2565.74^{h}$ & 10.07 \\
\hline \multirow[t]{3}{*}{ Daily Feed intake(g/b/d) } & 2 & $96.26^{\mathrm{b}}$ & $93.81^{c}$ & $91.30^{d}$ & 0.63 \\
\hline & 4 & $101.15^{a}$ & $90.04^{e}$ & $79.58^{g}$ & 0.53 \\
\hline & 6 & $100.69^{a}$ & $81.29^{f}$ & $61.09^{\mathrm{h}}$ & 0.58 \\
\hline \multirow[t]{3}{*}{ Feed: gain } & 2 & $2.06^{c}$ & $2.30^{a b c}$ & $2.33^{\mathrm{bc}}$ & 1.04 \\
\hline & 4 & $2.23^{\mathrm{ab}}$ & $2.42^{\mathrm{a}}$ & $2.26^{c}$ & 1.01 \\
\hline & 6 & $2.22^{\mathrm{ab}}$ & $2.48^{\mathrm{abc}}$ & $1.91^{\mathrm{d}}$ & 0.08 \\
\hline \multirow[t]{3}{*}{ Mortality (\%) } & 2 & 4.16 & 0 & 4.16 & 1.99 \\
\hline & 4 & 4.16 & 4.16 & 4.16 & 3.66 \\
\hline & 6 & 4.16 & 4.16 & 4.16 & 3.69 \\
\hline
\end{tabular}

a,b,c,dMeans in the same row not sharing common superscript are significantly different $(p<0.05)$. SEM: Standard error mean. 
able to compensate after the more severe feed restriction. Studies have shown that the longer the period of undernutrition, the more difficult it is for broiler chickens to compensate for reduction in live weight $(\mathrm{Yu}$ and Robinson, 1992). Zubair and Leeson (1994) have concluded that this effect is simply related to reduce maintenance energy needs of a smaller body mass at any time up to the time of growth compensation. Feed: gain ratio was superior for birds subjected to higher level and longer period of feed restriction (40\% for 6 weeks) compared to the ones on ad libitum. These results are consistent with previous reports (Palo et al., 1995 and Camacho et al., 2004).

Pokniak and Cornejo (1982) and Pokniak et al. (1984) reported improved feed efficiency, but they noticed no significant difference in body composition between previously restricted and full-fed chickens at 8 weeks of age. Most notably, Plavnik and co-workers (Plavnik and Hurwitz, 1985; Plavnik et al., 1986 and McMurtry et al., 1988) obtained improved feed efficiency, reduced body fat and abdominal fat and no reduction of final body weight in broiler chickens subjected to severe early feed restriction (70\%). The body composition of broiler chickens can be significantly altered by protein level of the diet and frequency of feeding. Some investigators have reported a reduction in mortality rate following feed restriction (Bowes et al., 1988; Arce et al., 1992). This could provide the greatest economic incentive for implementing early feed restriction by allowing for more birds to be marketed from a flock. In this study, mortality was not significantly affected by the feed restriction programme and did not follow a particular pattern so it cannot be established if it was caused by restriction. This is similar to results reported by Oyedeji and Atteh (2005). However, the present results (table IV) are contrary to the findings of Saleh et al. (2005) who reported that level of feed had effects on mortality of the broiler chickens.

In this study, abdominal fat was greatly reduced with severity of restriction. This might be due to fat mobilization for energy supply and abdominal fat might be mobilized more easily during a fasting period. A reduction in abdominal fat content with concomitant reduction in body weight were found by Plavnik and Hurwitz (1986) and Jones and Farrell (1992). Other investigators have reported reductions in abdominal fat pad due to early life feed restriction but a small reduction in final body weight (Lippens et al., 2000). Beane et al. (1979) reported that feed efficiency was improved, but the

Table IV. Main effect of duration and level of feed restriction on abdominal fat and proximate composition of breast muscle of Marshall broilers. (Efecto de la duración y nivel de restricción alimenticia sobre la grasa abdominal y composición de la pechuga de pollos broiler Marshall).

\begin{tabular}{lcccccccc}
\hline & \multicolumn{4}{c}{ Duration } & of feed restriction & (weeks) & \multicolumn{4}{c}{ Level of feed restriction (\%) } \\
Parameters & 2 & 4 & 6 & SEM & 0 & 20 & 40 & SEM \\
\hline Abdominal fat & $0.54^{\mathrm{a}}$ & $0.47^{\mathrm{b}}$ & $0.34^{\mathrm{c}}$ & 0.07 & $0.52^{\mathrm{a}}$ & $0.50^{\mathrm{a}}$ & $0.33^{\mathrm{b}}$ & 0.07 \\
Crude protein & $18.22^{\mathrm{c}}$ & $19.59^{\mathrm{b}}$ & $22.82^{\mathrm{a}}$ & 0.37 & $18.71^{\mathrm{b}}$ & $20.44^{\mathrm{a}}$ & $21.49^{\mathrm{a}}$ & 0.37 \\
Crude fat & 17.61 & 17.49 & 17.02 & 0.19 & $17.95 \mathrm{~b}$ & $17.42 \mathrm{~b}$ & $16.74 \mathrm{a}$ & 0.19 \\
Ash & $5.22^{\mathrm{a}}$ & $5.01^{\mathrm{ab}}$ & $4.70^{\mathrm{b}}$ & 0.12 & $5.18^{\mathrm{a}}$ & $5.09^{\mathrm{a}}$ & $4.66^{\mathrm{b}}$ & 0.12 \\
Nitrogen free extract & $31.00^{\mathrm{b}}$ & $32.20^{\mathrm{a}}$ & $33.00^{\mathrm{a}}$ & 0.40 & $33.20^{\mathrm{a}}$ & $32.00^{\mathrm{b}}$ & $31.60^{\mathrm{b}}$ & 0.41 \\
\hline
\end{tabular}

$a, b, c$ Means in the same row not sharing common superscript are significantly different $(p<0.05)$. SEM: Standard error mean. 
amount of abdominal fat in male broilers was significantly increased. Feed-restricted birds have been shown to have lower carcass fat content at market age than birds fed ad libitum (Cabel and Waldroup, 1990). Summers et al. (1990) and Jones and Farrell (1992) did not find changes in carcass composition of birds after feed restriction conditions; however, Plavnik and Hurwitz (1985, 1989) and Plavnik et al.(1986) reported a decrease in fat pad on birds restricted from 6 to 12 days of age, without adverse effects on growth. The same effect of restriction on the amount of carcass fat was found by Plavnik and Hurwitz (1985), but with lower body weight gain in relation to the ad libitum birds, perhaps due to the restriction severity (70\% of the ad libitum feed intake). Fontana et al. (1992) reported a larger abdominal fat deposition in the carcass of restricted birds after refeeding. According to Pinchasov and Jensen (1989), fat pad is more directly influenced by nutrition than total carcass fat. Most of these studies reported improved feed efficiency and a reduction of body fat and abdominal fat, but with final body weight somewhat reduced. There are exceptions; for example $\mathrm{Yu}$ et al. (1990) found no significant difference in overall feed efficiency between restricted and full-fed broilers. Zubair and Leeson (1994) showed that feed-restricted birds usually had a numerically smaller abdominal fat pad. This agrees with the current results. Feed restriction brought about the reduction of abdominal fat as reported by Griffiths et al. (1977), Arafa et al. (1983) and Pinchasov et al. (1985). However, this study proves that abdominal fat is a perfect indicator to estimate meat fat content.

At 56 days of age, compared with the ad libitum broilers, crude protein (CP) content of breast muscle was higher in feedrestricted broilers, whereas the ash content varied across the treatments. The results are consistent with previous reports (Gondret et al., 2000; Gondret and Lebret, 2002). During feed restriction, broilers con-

Table $V$. Interactive effect of duration and level of feed restriction on abdominal fat and proximate composition of breast muscle of Marshall broilers. (Efecto interactivo entre la duración y nivel de restricción alimenticia sobre la grasa abdomninal y composición de la pechuga de pollos broiler Marshall).

\begin{tabular}{lccccc}
\hline & $\begin{array}{c}\text { Duration } \\
\text { (weeks) }\end{array}$ & 0 & $\begin{array}{c}\text { Level } \\
20\end{array}$ & 40 & SEM \\
\hline Abdominal fat pad (\% LW) & 2 & $0.59^{\mathrm{ab}}$ & $0.41^{\mathrm{ab}}$ & $0.40^{\mathrm{a}}$ & 0.07 \\
& 4 & $0.66^{\mathrm{a}}$ & $0.59^{\mathrm{a}}$ & $0.37^{\mathrm{ab}}$ & 0.1 \\
& 6 & $0.57^{\mathrm{a}}$ & $0.41^{\mathrm{ab}}$ & $0.20^{\mathrm{b}}$ & 0.13 \\
Crude protein (\%) & 2 & $17.60^{\mathrm{d}}$ & $18.41^{\mathrm{cd}}$ & $18.65^{\mathrm{cd}}$ & 0.37 \\
& 4 & $18.31^{\mathrm{cd}}$ & $19.44^{\mathrm{bcd}}$ & $21.05^{\mathrm{b}}$ & 0.48 \\
Crude fat (\%) & 6 & $20.23^{\mathrm{bc}}$ & $23.24^{\mathrm{a}}$ & $25.00^{\mathrm{a}}$ & 0.65 \\
& 2 & $17.40^{\mathrm{abc}}$ & $16.92^{\mathrm{bcd}}$ & $16.73^{\mathrm{cd}}$ & 0.19 \\
NFE (\%) & 4 & $18.29^{\mathrm{a}}$ & $17.88^{\mathrm{ab}}$ & $16.29^{\mathrm{d}}$ & 0.21 \\
& 6 & $18.16^{\mathrm{a}}$ & $17.46^{\mathrm{abc}}$ & $17.20^{\mathrm{abcd}}$ & 0.33 \\
& 2 & $33.20^{\mathrm{ab}}$ & $31.11^{\mathrm{bc}}$ & $32.10^{\mathrm{bc}}$ & 0.4 \\
& 4 & $31.22^{\mathrm{abc}}$ & $32.43^{\mathrm{bc}}$ & $30.43^{\mathrm{bcd}}$ & 0.54 \\
& 4 & $33.55^{\mathrm{a}}$ & $32.00^{\mathrm{bc}}$ & $31.67^{\mathrm{abc}}$ & 0.71 \\
\hline
\end{tabular}

a,b,c,dMeans in the same row not sharing common superscript are significantly different $(p<0.05)$. SEM: Standard error mean. 
sume less protein than the control and it has been observed that total protein depend on quality and quantity of protein supplied in the diet (Iyayi and Tewe, 1998). Lower pro-

Table VI. Effect of duration and level of feed restriction on cost benefit of Marshall broilers. (Efecto de la duración y nivel de restricción alimenticia sobre la relación coste/beneficio de pollos broiler Marshall).

\begin{tabular}{|c|c|c|c|}
\hline & 0 & $\begin{array}{c}\text { Level } \\
20\end{array}$ & 40 \\
\hline \multicolumn{4}{|c|}{ Cost of chicks (US\$) } \\
\hline 2 & 21.68 & 21.68 & 21.68 \\
\hline 4 & 21.68 & 21.68 & 21.68 \\
\hline 6 & 21.68 & 21.68 & 21.68 \\
\hline \multicolumn{4}{|c|}{ Feed consumed (kg/bird) } \\
\hline 2 & 0.03 & 0.03 & 0.03 \\
\hline 4 & 0.03 & 0.02 & 0.02 \\
\hline 6 & 0.02 & 0.02 & 0.02 \\
\hline \multicolumn{4}{|c|}{ Feed price/kg (US\$) } \\
\hline 2 & 0.46 & 0.46 & 0.46 \\
\hline 4 & 0.46 & 0.46 & 0.46 \\
\hline 6 & 0.46 & 0.46 & 0.46 \\
\hline \multicolumn{4}{|c|}{ Total feed cost (US\$) } \\
\hline 2 & 45.07 & 47.35 & 47.14 \\
\hline 4 & 43.92 & 42.15 & 38.06 \\
\hline 6 & 42.74 & 37.25 & 28.59 \\
\hline \multicolumn{4}{|c|}{ Labour and Drugs (US\$) } \\
\hline 2 & 19.35 & 19.35 & 19.35 \\
\hline 4 & 19.35 & 19.35 & 19.35 \\
\hline 6 & 19.35 & 19.35 & 19.35 \\
\hline \multicolumn{4}{|c|}{ Total cost of production (US\$) } \\
\hline 2 & 86.10 & 88.39 & 88.17 \\
\hline 4 & 84.95 & 83.18 & 79.09 \\
\hline 6 & 83.77 & 78.28 & 69.63 \\
\hline \multicolumn{4}{|c|}{ Sale price per kg/live weight (US\$) } \\
\hline 2 & 7.42 & 7.10 & 7.10 \\
\hline 4 & 7.42 & 7.10 & 7.10 \\
\hline 6 & 7.42 & 7.10 & 6.97 \\
\hline \multicolumn{4}{|c|}{ Cost/ kg/ live weight (US\$) } \\
\hline 2 & 178.06 & 170.32 & 170.32 \\
\hline 4 & 178.06 & 170.32 & 170.32 \\
\hline 6 & 178.06 & 170.32 & 167.23 \\
\hline \multicolumn{4}{|c|}{ Revenue/kg/ live weight (US\$) } \\
\hline 2 & 91.96 & 81.94 & 82.15 \\
\hline 4 & 93.11 & 87.14 & 91.23 \\
\hline 6 & 94.29 & 92.04 & 97.60 \\
\hline
\end{tabular}

tein consumption may improve mineral metabolism. This assumption was based on the finding of Hulan et al. (1980) who found that lower protein consumption would reduce leg abnormality. The findings of Robinson et al. (1999) also showed that lowering growth at an early age would allow the bone grow faster at optimum rate. Niret al. (1996) and Katanbaf et al. (1988) found that restricted chicks had heavier digestive tract. Cherry et al. (1978) showed that chickens with heavier relative digestive tract weight had slower gastro-intestinal clearance than those with lighter digestive tract. A slower clearance of feed from the intestinal tract allows the nutrients (i.e. minerals) greater exposure to the absorptive cells and consequently influences the efficiency of nutrient utilization. This study showed that birds restricted for 6 weeks duration had lowest fat content in breast muscle. The study also showed (table V) that the lower the abdominal fat and breast muscle fat content, the higher the protein.In general, duration of feed restriction increased ash content at 2 and 4 weeks within increasing levels but reduced at 6 weeks with increasing levels.

Feed restriction affected the live weight of broiler chickens at 56 days of age. Chickens on $20 \%$ restriction attained little compensation in live weight but did not achieve up to the control birds while those on $40 \%$ restriction did not. Thus, $20 \%$ restriction was beneficial in terms of saving feed. It may, therefore, be a useful tool to reduce the cost (table VI) of starter feed, without any adverse effect on the final body weight of the chickens. However, generally from this study, total feed cost per bird was reduced by increasing durations and levels of feed restriction.

It can be concluded that the best feed:gain, lower abdominal fat, better mea quality and better cost benefit was achieved in birds restricted at $40 \%$ for 6 weeks. The diet therefore produced lean meat at reduced 
cost which can be of advantage to the producer and beneficial to the consumer.

\section{CONCLUSION}

Restricting feed intake from 2 to 4 and 6 weeks significantly reduced final body weight gain with no evidence of compensatory gain. Feed intake following restriction was also significantly reduced at all ages. Feed conversion following restricted feed intake was improved. Feed: gain was better in birds restricted at 6 weeks at $40 \%$. Mortality was not significant throughout the trial and did not follow a

\section{REFERENCES}

Aduku, A.O. 2004. Feed composition and nutrition. Composition alimentaire. Dept of Animal Science. Ahmadu Bello University. Zaria. Nigeria. 8 pp.

Al-Taleb, S.S. 2003. Effect of an early feed restriction productive performance and carcass quality. Online J Biol Sci, 36: 607-611 (26/06/ 2012).

Arafa, AS.; Boone, M.A.; Janky, D.M.; Wilson, M.K.; Miles, RD and Harms, M.S. 1983. Energy restriction as a means of reduction of fat pads in broilers. Poultry Sci, 62: 314-420.

Arce, J.; Berger, M. and Coello, C.L. 1992. Control of ascites syndrome by feed restriction techniques. J Appl Poultry Res, 1: 1-5.

AOAC. Association of Official Analytical Chemists. 1995. Official methods of Analysis. 16th ed. AOAC. Arlington. Virginia. USA.

Beane, W.L.; Cherry J.A. and Weaver Jr., W.D. 1979.Intermittent light and restricted feeding of broiler chickens. Poultry Sci, 58: 567-571.

Bowes, V.A.; Julian, R.J.; Leeson, S. and Stirtzinger, T. 1988. The effect of feed restriction on feed efficiency and incidence of sudden death syndrome in broiler chickens. Poultry Sci, 67: 1102-1104.

Cabel, M.C. and Waldroup, P.W. 1990. Effect of different nutrient-restriction programs early in life on broiler performance and abdominal fat content. Poultry Sci, 69: 652-660.

Camacho, M.A.; Suarez, M.E.; Herrera, J.G., Cuca, J.M. and Garcia-Bojalil, C.M. 2004. Effect of age of feed restriction and microelement supple- particular pattern so it cannot be established if it was caused by restriction. Duration and level of feed restriction affected performance and abdominal fat pad. However, chickens on 20 and $40 \%$ ad libitum feeding did not 'catch-up' with those on ad libitum feeding in terms of live weight.

Feed restriction had effect on nutrient content of breast muscle except ash and NFE. Crude protein increased while other nutrients decreased as feed restriction increased. Crude fat content was lowest at $40 \%$ level of restriction. Hence, restricting feed at $40 \%$ for 6 weeks is recommended based on better feed:gain and meat quality.

mentation to control ascites on production and carcass characteristics of broilers. Poultry Sci, 83: 526-532.

Chambers, J.R. 1990. Genetics of growth and meat production in chickens. In: Poultry breeding and genetics. Crawford, R.D. (Ed.). Elsevier Science Publishers B.V. Amsterdam. Netherlands. pp: 599-643.

Cherry, J.A.; Siegel, P.B and Beane, W.L. 1978. Genetic-nutritional relationships in growth and carcass characteristics of broiler chickens. Poultry Sci, 57: 1482-1487.

Crouch, A. N. 2000. The effects of physical feed restriction on body composition and reproductive performance of commercial large white turkey breeder hens and its subsequent economic impact. PhD thesis. North Carolina State University. U.S.A.

Fontana, E.A.; Weaver Jr, W.D.; Watkins, B.A. and Denbow, D.M. 1992. Effect of early feed restriction on growth, feed conversion and mortality in broiler chickens. J Poultry Sci, 71: 296-305.

FUNAAB. 2013. Policy on research of the Federal University of Agriculture. Abeokuta. Nigeria. http://www.unaab.edu.ng (04/08/2013).

Gondret, F. and Lebret, B. 2002. Feeding intensity and dietary protein level affect adipocyte cellularity and lipogenic capacity of muscle homogenates in growing pigs, without modification of the expression of sterol regulatory element binding protein. J Anim Sci, 


\section{OMOSEBI, ADEYEMI, SOGUNLE, IDOWU AND NJOKU}

80: 3184-3193.

Gondret, F.; Lebas, F. and Bonneau, M. 2000. Restricted feed intake during fattening reduces intramuscular lipid deposition without modifying muscle fiber characteristics in rabbits. J Nutr, 130: 228-233.

Gous, R.M. and Cherry, P. 2004. Effects of body weight at, and lighting regimen and growth curve to, 20 weeks on laying performance in broiler breeders. Brit Poultry Sci, 45: 445-452.

Griffiths, L., Leeson, S. and Summers, J.D. 1977. Fat deposition in broilers: Effect of dietary energy to protein balance and early life caloric restriction on productive performance and abdominal fat pad size. Poultry Sci, 56: 638-646.

Hocking, P.M.; Bernard, R. and Robertson, G.W. 2002. Effects of low dietary protein and different allocations of food during rearing and restricted feeding after peak rate of lay on egg production, fertility and hatchability in female broiler breeders. Brit Poultry Sci, 43: 94-103.

Hornick, J.L.; Van Eenaeme, C.; Gerard, O.; Dufrasne, I. and Istasse, L. 2000. Mechanisms of reduced and compensatory growth. Dom Anim Endocrinol, 19: 121-132.

Hulan, H.W.; Proudfoot, F.G.; Ramey, D. and McRae, K.B. 1980. Influence of genotype and diet on general performance and incidence of leg abnormalities of commercial broilers reared to roaster weight. Poultry Sci, 59: 748-757.

lyayi E.O. and Tewe O.O. 1998.TSP, urea and creatine levels as indices of quality of cassava diets for pigs. Trop Vet, 16: 57-67.

Jones, G.P.D. and Farrell, D.J. 1992. Early-life food restriction of chicken. Methods of application, amino acid supplementation and the age at which restriction should commence. Brit Poultry Sci, 33: 579-587.

Katanbaf, M.N.; Dunnington, E.A. and Siegel, P.B. 1988. Allomorphic relationships from hatching to 56 days in parental lines and F1 crosses of chickens selected 27 generations for high or low body weight growth and development. Aging, 52: 11-22.

Kessler, A.M.; Snizek Jr., P.N. and Brugalli, I. 2000. Manipulação da quantidade de gordura na carcaça de frangos. Anais da Conferência APINCO de Ciência e Tecnologia Avícolas. APINCO. Campinas, SP. Brazil. pp. 107-133.

Leeson, S. and Summers, J.D. 2005. Feeding programs for broiler chickens: growth restriction. Commercial Poultry Nutrition. $3^{\text {rd }}$ ed.University Books. Guelph. Ontario. pp. 248-251.

Lippens, M.; Room, G.; DeGroote, G. and Decuypere, E. 2000. Early and temporary quantitative food restriction of broiler chickens. Effects on performance characteristics, mortality and meat quality. Brit Poultry Sci, 41: 343-354.

Merck. 2011. Merck Manual. Nutritional requirements of poultry. Merck Sharp \& Dohme Corp. Whitehouse Station. New Jersey, USA. http:// www.merckvetmanual.com/mvm/index.jsp? cfile $=$ htm/bc/171315.html (07/09/12).

Mench, J.A. 2002. Broiler breeders: Feed restriction and welfare. World Poultry Sci J, 58: 20-29.

McMurtry, J.P.; Rosebrough, R.W.; Plavnik, I. and Cartwright, A.L. 1988. Influence of early plane of nutrition on enzyme systems and subsequent tissue deposition. Biomechanisms regulating growth and development. Beitsville Symposium on Agricultural Research. No.12. Steffens, G.L. and Rumsey, T.S. (Eds.). Klumer. Academic Publishers. Dordrecht. The Netherlands. pp. 329-341.

Nir, I.; Nitsan, Z.; Dunnington, E.A. and Siegel, P.B. 1996. Aspects of food intake in young domestic fowl: Metabolic and genetic considerations. World Poultry Sci J, 52: 251-266.

Oyedeji, J.O. and Atteh, J.O. 2005.Response of broilers to feeding manipulations. International $J$ Poultry Sci, 4: 91-95.

Palo, P.E.; Sell, J.L.; Piquer, F.J.; Vilaseca L. and Soto-Salanova, M.F. 1995. Effect of early nutrient restriction on broiler chicken, performance and development of the gastrointestinal tract. Poultry Sci, 74: 88-101.

Pinchasov, Y. and Jensen, L.S. 1989. Comparison of physical and chemical means of feed restriction in broiler chicks. Poultry Sci, 68: 61-69.

Pinchasov, Y.; Nir, I. and Nitsan, I. 1985. Metabolic and anatomical adaptations of heavy-bodied chicks to intermittent feeding. Food intake, growth rate, organ weight, and body composition. Poultry Sci, 64: 2098-2109.

Pinheiro, D.F.; Cruz, V.C.; Sartori, J.R. and Vicetini Paulino, M.L. 2004. Effect of early feed restriction and enzyme supplementation on digestive enzyme activities in broilers. Poultry Sci, 83: 1544-1550.

Archivos de zootecnia vol. 63, num. 244, p. 620. 


\section{FEED RESTRICTION AND PERFORMANCE AND MEAT QUALITY OF BROILERS}

Plavnik, I. and Hurwitz, S. 1985. The performance of broiler chicks following a severe feed restriction at an early age. Poultry Sci, 64: 348355.

Plavnik, I. and Hurwitz, S. 1989. Effect of dietary protein, energy and feed pelleting on the response of chicks to early feed restriction. Poultry Sci, 68: 1118-1125.

Plavnik, I.; McMurtry J.P. and Rosebrough, R.W. 1986. Effect of early feed restriction in broilers. Growth performance and composition. Growth, 50: 68-76.

Pokniak, J.A. and Cornejo S.B. 1982. Effects of energy and protein under nutrition on productive performance and carcass, liver, and digestive tract composition of broiler males. Nutr Rep Int, 26: 319-327.

Pokniak, J.A.; Avaria, M.S. and Cornejo, S.B. 1984. Productive performance and changes in carcass composition of broilers under an initial energyprotein restriction and subsequent refeeding. Nutr Rep Int, 30: 1377-1383.

Rezaei, M.; Teimouri, A.; Pourreza, J.; Syyahzadeh, H. and Waldroup, P.W. 2006. Effect of diet dilution in the starter period on performance and carcass characteristics of broiler chicks. J Central Europ Agric, 7: 63-70.

Robinson, F.E.; Classen, H.L.; Hanson, J.A. and Onderka, D.K. 1999. Growth performance, feed efficiency and the incidence of skeletal and metabolic disease in full-fed and feed-restricted broiler and roaster chickens. J Appl Poultry Res, 1: 33-41.

Saleh, E.A.; Watkins, S.E.; Waldroup, A.L. and Waldroup, P.W. 2005. Effects of early feed restriction of live performance and carcass composition of male broilers grown for further processing. Poultry Sci Ass, 14: 87-93.

Smith, A.J. 1990. Poultry tropical agriculturist series. Macmillan. Ibadan. pp. 138-147.

SPSS. 1999. Statistical package for social science.
SPSS for windows (version 6.1). SPSS Inc. Chicago. USA.

Steel, R.G.D.; Torrie J.H. and Dickey, D.A. 1997.Principles and procedures of statistics. A biochemical approach. $2^{\text {nd }}$ ed. McGraw Hill Book Co. Inc. New York. USA.

Summers, J.D.; Spratt, D. and Atkinson, J.L. 1990. Restricted feeding and compensatory growth for broilers. Poultry Sci, 69: 1855-1861.

Teimouri, A.; Razaei, J.; Pourreza, J.; Sayyazadeh, H. and Waldroup, P.W. 2005 Effect of diet dilution in starter period on performance and carcass characteristics of broiler chicks. Int J Poultry Sci, 4: 1006-1011.

Tolkamp, B.J.; Sandilands, V. and Kyriazakis, I. 2005. Effects of qualitative feed restriction during rearing on the performance of broiler breeders during rearing and lay. Poultry Sci, 84: 1286-1293.

Urdaneta-Rincon, M. and Leeson, S. 2002. Quantitative and qualitative feed restriction on growth characteristics of male broiler chickens. Poultry Sci, 81: 679-688.

Washburn, K.W. and Bondari, K. 1978. Effects of timing and duration of restricted feeding on compensatory growth in broilers. Poultry Sci, 57: 1013-1021.

Yu, M.W. and Robinson, E.E. 1992. The application of short-term feed restriction to broiler chicken production: a review. J Appl Poultry Res, 1: 147-153

Yu, M.W.; Robinson, F.E.; Clandinin, M.T. and Bodnar, L. 1990. Growth and body composition of broiler chickens in response to different regimens of feed restriction. Poultry Sci, 69: 2074-2081.

Zubair, A.K. and Leeson, S. 1994. Effect of early feed restriction and realimentation on metabolicheat production and changes in digestive organs in broiler chickens. Poultry Sci, 73: 529538. 